matter, but this does not seem to have been the casew ith Gay-Lussac.

The author declares "this biography will help give flesh and bones to one of the names found in science textbooks but, in so doing, it may also make a small contribution to a fuller understanding of the development of science". I believe that he is both over-sanguine and too modest. For me, at least, Gay-Lussac never emerges as a rounded human personality. Here and there we catch glimpses of a somewhat unbending autocrat tending to inspire respect rather than affection and himself under pressure from a financially ambitious wife. But in fact we learn little of his family life, his hobbies ("no great interest in the arts") or his religion (Enlightenment humanism). We do not even know the circumstances of his death. On the other hand, for science itself the book makes more than the "small contribution" suggested by the author. It is a solid piece of research meticulously executed with tables, footnotes, bibliographies, appendix and indexes, and is a substantial addition to our understanding of the development of chemistry at an important stage of its history. At $£ 15$ one might have expected the publishers to allow the author more illustrations than the solitary portrait that appears as the frontispiece. But we must be grateful to Gay-Lussac for having contributed so much to chemical science and to Marırice Crosland for an illuminating and soundly-constructed essay in scientific biography.

Colin A. Russell is Reader in the History of Science and Technology at the Open University, Milton Keynes, UK.

\section{Salt in}

perspective

\section{Frank Greenaway}

Neptune's Gift: A History of Common Salt. By R. P. Multhauf. Pp. 325. (Johns Hopkins University Press: Baltimore and London, 1978.) $\mathfrak{£ 1 5 . 7 5 .}$

"SALT was known to the Ancients". So began for fifty years the lectures on the halogens given by an imperishable Oxford don. Robert Multhauf might well have begun his excellent book with the same words, conveying as they do the antiquity and continuity of his subject. A book which is primarily historical in intent, but concludes with a reference dated 1976 is, to say the least, unusual, but Multhauf is an unusual man.

He has been a man of action and saw the world before entering on a career at the Museum of History and Technology at the Smithsonian Institution which made him so well known as a leading historian of chemistry. His reach is long and his grasp firm. This work on salt has all the fluency and density of significant detail which make his earlier work The Origins of Chemistry so valuable.

The book falls into two main sections: "The Age of Culinary Salt" and "The Era of Chemical Salt". The transition is set later than would seem obvious-that is, in the nineteenth rather than the seventeenth century. Multhauf sees the food preservative role of salt as its more important feature well into the nineteenth century. Only with the expansion of the chemical industry as a whole and the concomitant expansion of large-scale manufacturing industry and long distance bulk transport does he depict salt as a key chemical raw material.

Salt is a universal necessity. Without an adequate intake, direct or indirect, normal health cannot be maintained. Yet salt is not so widespread a natural substance as might seem from its invariable association with animal life. It has to be sought by human and animal alike; so since ancient times, it has had the scarcity value which makes for trading and taxation. A history of administration could be written around salt, "an ideal article for fiscal management". There was a universal demand for it, its supply could not be left to chance and it was a fairly easy commodity to control, as was found not only in Europe but also in China and elsewhere. The salt tax, the gabelle, was hated in France and seems to have been one of the precipitating causes of the French Revolution. However, one must not take too simple a view of the historic role of salt taxes, which came and went in a very irregular way in the United States, and were much confused in Indian history by the close relationship of salt with the important saltpetre industry and trade.

The extraction of salt is an exceptional example of the stability and continuous survival of techniques which, though crude and simple, were efficient enough to render modification unnecessary for centuries. There were several methods, some of which might be found in use within a short distance of each other: evaporation of seawater by fire or solar heat, surface mining, deep mining, leaching, and so on. Simple pottery pans for boiling down brine were so customary that their fragmentary remains are good evidence of the existence of a salt industry. The largest salt industries, however, were eventually those based on deep-mined rock-salt, the demand being that of the new chemical industries. (One of several sections contributing to the wider history of technology is that dealing with drilling.)

Before salt entered its modern phase of being the raw material for sodium compounds and for chlorine, it was one of the most important means of sheer survival, being an invaluable food preservative. Lynn White has drawn attention to the importance of improved second-class protein supplies to the development of mediaeval technical vigour, but the argument can be continued: new technical improvements in salt manufacture improved the availability of meat and fish protein and so progressively helped to bring about the energising of Western Europe which ushered in what we can still usefully call Modern Times. But even greater expansion was to come as salt-mining benefited from the steam-engine and the development of iron machinery. Multhauf uses an enlightening analogy: comparing early salt-mining to an agricultural pursuit because of its often seasonal character, and showing how it was transformed into a nonseasonal industry. By 1850 the alkali industry took up about a third of British salt production. In the United States, the new meat-packing industry called for a great deal, but industria!ised food preservation was much less important elsewhere. Direct culinary use levelled off about 1850 , using about half of the British total at that time. The industry expanded, however, and the second half of the book explains why. The nineteenth-century chemical industry had soda as one of its pillars with salt as the base, and the vast increase in the use of salt-derived chlorine in solvents, plastics, pesticides and the like. Multhauf points out how in the case of salt, as with so many other substances, the dominant industry is the automobile industry, using the plastics and solvents, which need chlorine, in direct manufacture, but also using very large amounts of salt as such for road treatment in winter.

The book is well produced, particularly well documented, and equipped with valuable maps and statistical tables.

Salt was known to the ancients, but, in spite of its importance, is little considered today in the perennial discussion of the effects of technology. Neptune's Gift should do much to equip us to see it in its correct perspective.

Frank Greenaway is Keeper of the Depart. ment of Chemistry at the Science Museum, London, UK. 